\title{
Product formation and phosphoglucomutase activities in Lactococcus lactis: cloning and characterization of a novel phosphogluco- mutase gene
}

\author{
Ny Qian, ${ }^{1}$ Grant A. Stanley, ${ }^{2}$ Annicka Bunte ${ }^{1}$ and Peter Rådström ${ }^{1}$
}

Author for correspondence: Peter Rådström. Tel: +46 46 2223412. Fax: +46 462224203. e-mail: Peter.Radstrom@tmb.lth.se

1 Department of Applied Microbiology, Lund Institute of Technology, Lund University, PO Box 124 , S-221 00 Lund, Sweden

2 Department of Food Technology, Victoria University, PO Box 14428, MCMC Melbourne, Victoria 8001, Australia

\begin{abstract}
Maltose metabolism in Lactococcus lactis involves the conversion of $\beta$-glucose 1-phosphate to glucose 6-phosphate, a reaction which is reversibly catalysed by a maltose-inducible and glucose-repressible $\beta$-phosphoglucomutase ( $\beta$ PGM). The gene encoding $\beta$-PGM (pgmB) was cloned from a genomic library of L. lactis using antibodies. The nucleotide sequence of a 5695 bp fragment was determined and six ORFs, including the pgmB gene, were found. The gene expressed a polypeptide with a calculated molecular mass of $24210 \mathrm{Da}$, which is in agreement with the molecular mass of the purified $\beta$-PGM (25 kDa). A short sequence at the $\mathbf{N}$-terminus was found to be similar to known metalbinding domains. The expression of $\beta$-PGM in $L$. lactis was found to be induced also by trehalose and sucrose, and repressed by lactose in the growth medium. This indicates that $\beta$-PGM does not serve solely to degrade maltose, but that it is also involved in the metabolism of other carbohydrates. The specific activity of $\beta$-PGM during fermentation was dependent on the maltose concentration in the medium. The maximum specific activity of $\beta$-PGM increased by a factor of $4 \cdot 6$, and the specific growth rate by a factor of 7 , when the maltose concentration was raised from 0.8 to $11.0 \mathrm{~g} \mathrm{I}^{-1}$. Furthermore, a higher amount of lactate produced relative to formate, acetate and ethanol was observed when the initial maltose concentration in the medium was increased. The specific activity of $\alpha$-PGM responded similarly to $\beta$-PGM, but the magnitude of the response was lower. Preferential sugar utilization and $\alpha$ - and $\beta$-PGM suppression was observed when $L$. lactis was grown on the substrate combinations glucose and maltose, or lactose and maltose; maltose was the least-preferred sugar. In contrast, galactose and maltose were utilized concurrently and both PGM activities were high throughout the fermentation.
\end{abstract}

Keywords: $\beta$-phosphoglucomutase, Lactococcus lactis, maltose, metabolism

\section{INTRODUCTION}

Phosphoglucomutase (PGM) catalyses the reversible transformation of D-glucose 6-phosphate to D-glucose 1phosphate, a key metabolic step in all cells (Ray \& Peck, 1972). Glucose 1-phosphate is required for the synthesis of UDPglucose, which is a precursor for the production

Abbreviation: $\beta$-PGM, $\beta$-phosphoglucomutase.

The EMBL accession number for the sequence of the DNA fragment containing the pgmB gene is 270730 . of glucose-containing polysaccharides. PGM activity is also essential for the glycolytic re-entry of glucose that has been stored as an energy reserve in forms such as glycogen and trehalose (Maréchal \& Belocopitow, 1974; Oh \& Hopper, 1990). Phosphorolysis of glucose oligoand polysaccharides usually yields $\alpha$-glucose 1 -phosphate as a product. However, maltose has been found to be phosphorylated by a maltose phosphorylase to $\beta$ glucose 1-phosphate and glucose in Lactobacillus, Neisseria and Lactococcus (Fitting \& Doudoroff, 1952; Maréchal et al., 1984; Moustafa \& Collins, 1968; Sjöberg et al., 1995). Trehalose phosphorylase, which 
splits trehalose to $\beta$-glucose 1-phosphate and glucose, has been described in Euglena (Maréchal \& Belocopitow, 1974). The $\beta$-glucose 1-phosphate formed is then converted to glucose 6 -phosphate by a $\beta$-specific PGM in these cells.

The presence of a $\beta$-PGM has also been reported in Entamoeba histolytica (Vargas \& Orozco, 1993) and Lactobacillus brevis (Maréchal et al., 1984), and is probably present in Neisseria (Ben-Zvi \& Schramm, 1961; Fitting \& Doudoroff, 1952). This indicates that there is a wide distribution of the enzyme in nature.

Two distinct forms of PGM have been purified from Lactococcus lactis growing on maltose: one is specific for $\alpha$-glucose 1-phosphate and the other is specific for $\beta$ glucose 1-phosphate (Qian et al., 1994). Although $\alpha$ PGM activity was present during both maltose and glucose utilization, it was found to be higher in maltosegrown lactococci. Unlike the constitutive expression of $\alpha$-PGM, the synthesis of $\beta$-PGM has been found to be induced by maltose and repressed by glucose. The molecular mass of the $\alpha$-PGM polypeptide is approximately $65 \mathrm{kDa}$ and its isoelectric point is $4 \cdot 4$. The corresponding values for $\beta$-PGM are $25 \mathrm{kDa}$ and 4.8 , respectively. These results indicate that there are differences in the amino acid sequence and biochemistry of the two PGM enzymes in lactococci.

There is little information about the regulation of both $\alpha$-PGM and $\beta$-PGM in cells or their influence on the cellular metabolism, although it has been suggested that the level of $\beta$-PGM activity and associated maltosecatabolic enzymes, the presumed permease and maltose phosphorylase, affects product formation in maltosegrown lactococci (Qian et al., 1994; Sjöberg et al., 1995). The premise is that the enzymes involved in the degradation of maltose affect the intracellular concentration of metabolic intermediates which regulate key enzymes, such as lactate dehydrogenase, in the fermentative pathway (Sjöberg et al., 1995). Here we describe the cloning of the $L$. lactis $\beta$-PGM gene, and present, as far as we know, the first known nucleotide sequence of a $\beta$-PGM gene. Furthermore, the regulation of both $\alpha$ - and $\beta$-PGM in lactococci growing on various carbohydrates was investigated, as was the formation of lactate, formate, acetate and ethanol.

\section{METHODS}

Bacterial strains, bacteriophages, plasmids and culture conditions. The strains, bacteriophages and plasmids used in this study and their relevant characteristics are listed in Table 1. Escherichia coli LE392 was used for $\lambda$ EMBL3 propagation, and E. coli JM83 was used for plasmid pUC18/19. To study the expression of $\beta$-PGM in E. coli, the cells were cultivated in LB medium supplied with ampicillin $\left(100 \mu \mathrm{g} \mathrm{ml}^{-1}\right)$ with or without IPTG $\left(0.5 \mu \mathrm{mol} \mathrm{ml}{ }^{-1}\right)$. The $\beta$-PGM gene was cloned from L. lactis 19435 obtained from the American Type Culture Collection. Chromosomal DNA was prepared from lactococci grown at $30^{\circ} \mathrm{C}$ in M17 medium (Terzaghi \& Sandine, 1975) containing maltose $\left(1 \mathrm{~g} \mathrm{l}^{-1}\right)$. To study the effect of various carbohydrates on growth, $\alpha$ - and $\beta$-PGM specific activity and product formation in L. lactis, strains 19435 and 65.1 were cultivated in the following rich medium containing $\left(\mathrm{l}^{-1}\right)$ : tryptone, $5 \mathrm{~g}$; yeast extract, $5 \mathrm{~g}$; Casamino acids, $1 \mathrm{~g}$; $\mathrm{K}_{2} \mathrm{HPO}_{4}, 2.5 \mathrm{~g} ; \mathrm{KH}_{2} \mathrm{PO}_{4}, 2.5 \mathrm{~g} ; \mathrm{MgSO}_{4} .7 \mathrm{H}_{2} \mathrm{O}, 0.5 \mathrm{~g} ; \mathrm{pH} 6.8$. This medium was supplemented with carbohydrates as follows $\left(1^{-1}\right): 1 \mathrm{~g}$ glucose, mannose, lactose, sucrose, maltose or trehalose for $\beta$-PGM induction experiments; 1 or $20 \mathrm{~g}$ maltose with $1 \mathrm{~g}$ glucose, lactose or galactose for mixed substrate fermentation experiments; $0.8,1.5,5.5$ or $11.0 \mathrm{~g}$ maltose to study the effect of maltose concentration on product formation and $\alpha$ - and $\beta$-PGM activity. For the mixed sugar and maltose concentration experiments, parent cultures were grown overnight on glucose $\left(20 \mathrm{~g} \mathrm{l}^{-1}\right)$, except for the experiments with lactose and galactose, in which case the parent culture was grown on lactose $\left(20 \mathrm{~g} \mathrm{l}^{-1}\right)$ or galactose $\left(20 \mathrm{~g} \mathrm{l}^{-1}\right)$, respectively. Anaerobic conditions were maintained by nitrogen flushing before inoculation and while sampling. Inocula were prepared by centrifuging $(5000 \mathrm{~g}, 10 \mathrm{~min})$ the parent culture, washing the pellet with carbohydrate-free medium, and resuspending the cells in fresh medium. The inoculum size was $5 \%(\mathrm{v} / \mathrm{v})$. Inocula were prepared from the same parent culture for the experiments examining the effect of maltose concentration on product formation and $\alpha$ - and $\beta$ PGM specific activity.

Experiments containing substrate combinations of maltose $\left(1.1 \mathrm{~g} \mathrm{l}^{-1}\right)$ and glucose were conducted in duplicate. The reproducibility of these experiments was $\pm 10.5 \%$ (specific growth rates), $\pm 15 \cdot 7 \%$ (initial $\beta$-PGM specific activity) and $\pm 7.6 \% \quad(\beta$-PGM specific activities attained after glucose expiration); these figures represent the standard deviation as a percentage of the mean. Single experiments were conducted for cultures with substrate combinations of maltose with either lactose or galactose, and maltose $\left(20 \mathrm{~g}^{-1}\right)$ with glucose. Triplicate experiments were performed for cultures with maltose at various concentrations (Fig. 4). The reproducibility of these experiments was $\pm 7 \cdot 1 \%$ (specific growth rates), $\pm 16.6 \%$ ( $\beta$-PGM specific activity) and $\pm 10.6 \%$ (the magnitude of the difference in relative lactate formation).

Measurement of growth, $\mathrm{pH}$, substrates and products. Cell growth was monitored by measuring the $\mathrm{OD}_{620}$ and the $\mathrm{pH}$ of the cultures was measured. Portions of the samples were centrifuged at $5000 \mathrm{~g}$ for $5 \mathrm{~min}$ (Microspin 24; Sorvall Instruments), and the supernatants were analysed for substrates and products. Glucose, maltose, galactose, lactate, formate, acetate and ethanol were detected with a differential refractometer (model RI-4; Varian) after separation of the compounds at $65^{\circ} \mathrm{C}$ on a prepacked Aminex HPX $87-\mathrm{H}$ column (Bio-Rad) by means of a Varian 9012 high performance liquid chromatograph. The mobile phase was

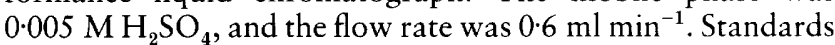
were injected separately. Quantification was accomplished by computer integration using Star Chromatography Systems software, version 4.0 (Varian). Carbohydrates for experiments containing maltose and lactose were measured using the following enzyme test kits from Boehringer Mannheim: lactose/D-galactose (cat. no. 176303) and maltose/sucrose/Dglucose (cat. no. 1113950)

Cell extracts, enzyme assays, SDSPAGE and Western blotting. At various times during culture growth, samples (200$500 \mathrm{ml}$ ) were collected and centrifuged at $5000 \mathrm{~g}$ at $4{ }^{\circ} \mathrm{C}$ for $5 \mathrm{~min}$. The cell pellet was washed twice and resuspended in $5 \mathrm{ml} 50 \mathrm{mM}$ triethanolamine (TEA) buffer containing $5 \mathrm{mM}$ $\mathrm{MgCl}_{2} \cdot 6 \mathrm{H}_{2} \mathrm{O}(\mathrm{pH} 7 \cdot 2)$. The cell suspensions were frozen at $-80^{\circ} \mathrm{C}$ and the cells were disrupted mechanically either by an X-press (Biox), MSK cell homogenizer (B. Braun) or by a 
Table 1. Bacterial strains, bacteriophages and plasmids used in this work

\begin{tabular}{|c|c|c|}
\hline Strain/phage/vector & Characteristics & Reference \\
\hline \multicolumn{3}{|l|}{ L. lactis strains } \\
\hline 19435 & $\mathrm{Lac}^{+}$ & ATCC \\
\hline 65.1 & $\mathrm{Lac}^{+}$ & Sjöberg \& Hahn-Hägerdal (1989) \\
\hline \multicolumn{3}{|l|}{ E. coli strains } \\
\hline LE392 & $\begin{array}{l}\text { supE44 supF58 bsdR514 glaK2 galT22 } \\
\text { metB1 trpR55 lacY1 }\end{array}$ & \\
\hline JM83 & ara (lac-pro $A B)$ lacZ $\Delta \mathrm{M} 15$ rpsL $\mathbf{\Phi 8 0}$ & \\
\hline \multicolumn{3}{|l|}{ Bacteriophages } \\
\hline ^EMBL3 & Cloning vector & Frischauf et al. (1983) \\
\hline$i 10$ & $\begin{array}{l}\text { AEMBL3 with } \mathrm{a} \sim 20 \mathrm{~kb} \text { Sau3A fragment } \\
\text { from the chromosome of } L . \text { lactis } 19435\end{array}$ & This study \\
\hline \multicolumn{3}{|l|}{ Plasmids } \\
\hline pUC18/19 & Cloning vector, $\mathrm{Ap}^{\mathrm{r}}$, lac $Z^{\prime}$ & Vieira \& Messing (1982) \\
\hline pNQ1 & $11 \mathrm{~kb}$ Sau $3 \mathrm{~A}$ fragment in pUC18 & This study \\
\hline pNQ2 & $5.7 \mathrm{~kb}$ PstI-Sau3A fragment in pUC19 & This study \\
\hline pNQ3 & $3.8 \mathrm{~kb}$ Sau3A-EcoRI fragment in pUC19 & This study \\
\hline pNQ4 & $2.6 \mathrm{~kb}$ Sau3A-EcoRI fragment in pUC19 & This study \\
\hline pNQ5 & $3 \cdot 3 \mathrm{~kb}$ HindIII fragment in pUC19 & This study \\
\hline pNQ6 & 787 bp PCR product in pUC19 & This study \\
\hline
\end{tabular}

multi-wrist shaker (Lab-line Instruments). Cell debris was removed by centrifugation $\left(10000 \mathrm{~g}, 4^{\circ} \mathrm{C}\right)$ for $10 \mathrm{~min}$. The supernatants were stored at $-80^{\circ} \mathrm{C}$ until used. The activities of $\alpha$ - and $\beta$-PGM were assayed as the conversion of $\alpha$ - or $\beta$ glucose 1-phosphate to glucose 6-phosphate by the formation of NADPH measured spectrophotometrically at $340 \mathrm{~nm}$ (Hitachi U-2000 spectrophotometer) as described by Ben-Zvi \& Schramm (1961). The protein concentration of the cell extracts was determined by the method of Bradford (1976). The protein assay reagent was from Pierce. All the reagents and equipment for SDS-PAGE were from Bio-Rad. SDSPAGE was done as described by Laemmli (1970). Denatured proteins from the cell extracts were separated by SDS-PAGE $(12.5 \%$ gels) and electrotransferred to PVDF membranes (Millipore) using an LKB 2117-005 Multiphor II NovaBlot Electrophoretic Transfer Unit (Pharmacia). Detection of $\beta$ PGM on nitrocellulose membranes was performed using rabbit polyclonal antisera (Qian et al., 1994) and a goat antirabbit alkaline phosphatase (GAR-AP) immunoblot kit (Bio$\mathrm{Rad}$ ) according to the manufacturer's instructions.

DNA techniques. Digestions, electrophoresis, electroelution, Southern blotting, hybridization and other DNA techniques were performed principally as described by Sambrook et al. (1989). Probe labelling and purification were conducted by the Random Primed DNA Labelling kit (USB) and Nick Column (Pharmacia). Chromosomal DNA of L. lactis 19435 was isolated essentially as described by Sambrook et al. (1989). Plasmid DNA was prepared using a Qiagen kit. Isotachophoresis and USBioclean (USB) were used for purification of DNA fragments from agarose gels.

PCR was used for automatic sequencing (see below) and for the amplification of the putative $\beta$-PGM gene and other DNA fragments. The reaction conditions for sequencing followed the protocol provided by the DyeDeoxy Terminator Cycle Sequencing kit (ABI, Applied Biosystems). Pwo DNA polymerase (Boehringer Mannheim) was used for the amplification of the $\beta$-PGM gene. The two primers used were $5^{\prime}$ -
ATGACGAGAAAGAAGG-3' and 5'-GGGCATCTGATTGGTT-3'. These are complementary to nucleotides 2034-2049 and 2813-2818, respectively, in the $5.7 \mathrm{~kb}$ sequenced Pst ISau3A fragment (Fig. 2).

Cloning protocols. A genomic library of L. lactis 19435 DNA fragments, partially digested with $S a u 3 A$, was prepared in $E$. coli LE392 by using the $\lambda$ EMBL3 Arms Cloning System and Packagene System (Promega). The genomic bank was screened for $\beta$-PGM expression by immobilizing bacteriophage $\lambda$ plaques on nitrocellulose filters (Sambrook et al., 1989) and using antibodies specific for $\beta$-PGM (Qian et al., 1994). Positive plaques were isolated and phage lysates were prepared for $\beta$ PGM assay and Western blot analysis to confirm the isolation of the $\beta$-PGM gene. Recombinant $\lambda$ DNA was subcloned into pUC18/19 using a pUC Cloning kit (Boehringer Mannheim). E. coli cells were transformed as described by Sambrook et al. (1989). Single colonies of $E$. coli transformants were grown in LB broth containing ampicillin and IPTG and cell extracts of the transformants were prepared for Western blot analysis. Finally, the putative gene was amplified by PCR from L. lactis chromosomal DNA and ligated into pUC19. The amplified fragment included a putative ribosome-binding site upstream of the gene. The insertion site was $55 \mathrm{bp}$ downstream of the initial codon ATG of the lac $Z^{\prime}$ gene encoding $\beta$-galactosidase.

To verify that the cloned fragment was identical to the corresponding chromosomal region, a Southern blot analysis was conducted. The recombinant plasmids and chromosomal DNA of L. lactis 19435 were digested and hybridized using the cloned fragment as a probe.

Nucleotide sequence and analysis. The DNA sequence of a 5695 bp Sau3A-Pst I fragment was determined both by the chain-termination method (Sanger et al., 1977) using the kit Sequenase version 2.0 (USB) and by the automatic DNA sequencing system (model 373A DNA Sequencing System and DyeDeoxy Terminator Cycle Sequencing kit; ABI, Applied Biosystems, product no. 401113). Double-stranded recom- 
binant plasmids from the subclones were used as template DNA. The primers used were either M13 sequencing primer $(-40)$, reverse sequencing primer or synthetic 20 -mer oligonucleotides synthesized by the Bio-Molecular Laboratory at Lund University, Sweden. The products of sequence reactions were purified by a Spin Down Column filled with Sephadex G50 DNA grade (Pharmacia) and resolved by electrophoresis on $8 \%(\mathrm{w} / \mathrm{v})$ polyacrylamide gels. The nucleotide sequence shown in this communication was determined from both strands. The resulting sequence was edited and assembled by SeqEd version 1.0.3 (Applied Biosystems) and analysed using the Genetics Computer Group software package of the University of Wisconsin.

Determination of the $\mathrm{N}$-terminal amino acid sequence of $\beta$-PGM. The $\beta$-PGM enzyme was partially purified by ammonium sulphate precipitation, gel filtration and ionexchange chromatography according to Qian et al. (1994). The material was dialysed against $10 \mathrm{mM} \mathrm{MgCl}_{2}, 5 \%(\mathrm{w} / \mathrm{v})$ glycerol, $0.5 \mathrm{mM}$ EDTA and $2 \mathrm{mM}$ 2-mercaptoethanol $(\mathrm{pH}$ $7 \cdot 3$ ), and proteins were precipitated with $14 \%$ trichloroacetic acid. The proteins were separated by SDS-PAGE and electroblotted onto an ImmobilonTM PVDF membrane (Bio-Rad). The $\beta$-PGM band was isolated, and the N-terminal end of the protein was deblocked by incubating the band for $23 \mathrm{~h}$ at $25^{\circ} \mathrm{C}$ in $0.1 \mathrm{M} \mathrm{HCl} /$ methanol. The $\mathrm{N}$-terminal amino acid sequence of $\beta$-PGM was determined by Edman degradation. Sequencing was done by the Department of Cell Research, Uppsala University (Uppsala, Sweden).

\section{RESULTS}

\section{Cloning and expression of the $\beta$-PGM gene in $E$. coli}

A genomic library of $L$. lactis 19435 was screened in $E$. coli with polyclonal antibodies raised against $\beta$-PGM. The screening resulted in the isolation of 10 recombinant $\lambda$ phages. Analysis of phage lysates by Western blotting revealed that two of these recombinant phages expressed a polypeptide of molecular mass approximately $25 \mathrm{kDa}$. This value was in agreement with the molecular mass of the purified $\beta$-PGM (Qian et al., 1994) as determined by gel filtration $(28 \mathrm{kDa})$ and SDS-PAGE $(25 \mathrm{kDa})$. The DNA insert from one of the two $\lambda$ phages was cloned into pUC18 for further analysis. The plasmid designated pNQ1 contained an $11 \mathrm{~kb}$ Sau3A fragment (Fig. 1). Southern blot analysis of the chromosomal DNA from L. lactis strain 19435 confirmed the restriction endonuclease map of pNQ1 shown in Fig. 1. A crude extract of $E$. coli JM83 harbouring pNQ1 showed $\beta$-PGM activity (Table 2 ). The specific activity was approximately 15 times lower than the activity observed in maltose-grown lactococci, even in the presence of IPTG. Various restriction fragments were subcloned into the vector pUC19 (Fig. 1). Plasmid pNQ2, containing a $5.4 \mathrm{~kb}$ Sau3A-PstI fragment, and plasmid pNQ3, containing a $3.8 \mathrm{~kb}$ Sau3A-EcoRI DNA fragment, showed moderately increased $\beta$-PGM activity as compared with pNQ1 (Table 2). When crude extracts were prepared from cultures grown with IPTG, the $\beta$-PGM specific activity doubled. This indicated that the transcription direction of the putative $\beta$-PGM gene was the same as that of the lac promoter in $\mathrm{pNQ} 2$ and $\mathrm{pNQ} 3$, but not in pNQ1. The two plasmids pNQ4 and pNQ5, containing a $2.6 \mathrm{~kb}$ Sau $3 \mathrm{~A}-E c o \mathrm{RI}$ fragment and a $3.3 \mathrm{~kb}$ HindIII fragment, respectively, showed no $\beta$-PGM activity or immunoreaction. Thus, the EcoRI site in $\mathrm{pNQ} 4$ and the $H$ indIII site in pNQ5 are located within the $\beta$-PGM gene.

\section{Sequence analysis of the $\beta$-PGM gene}

The nucleotide sequence of the 5695 bp Sau3A-Pst I fragment of $\mathrm{pNQ} 2$ was determined (Fig. 2). The analysed sequence covered the region of the predicted $\beta$ PGM gene and flanking DNA. Six ORFs were found (see Fig. 1; pNQ2). All ORFs except for ORF3 were directed in the same orientation as the lac promoter. The location of ORF2 was in agreement with the region mapped to contain the $\beta$-PGM gene. ORF2 predicted a polypeptide of 221 amino acid residues with a molecular mass of $24210 \mathrm{Da}$, which is slightly lower than the value determined for $\beta$-PGM by SDS-PAGE $(25 \mathrm{kDa})$. The calculated isoelectric point of 4.76 was also in agreement with the determined value $(4 \cdot 8)$ of the purified $\beta$-PGM enzyme (Qian et al., 1994). A sequence, $5^{\prime}$ AGAAAGAAGGT-3', complementary to the ShineDalgarno sequence $3^{\prime}$-UCUUUCCUCCA- $5^{\prime}$ at the $3^{\prime}$ end of L. lactis $16 \mathrm{~S}$ ribosomal RNA molecule (Ludwig et al., 1985), was recognized 7 bp before the ATG start. There is a region of dyad symmetry located between ORF1 and ORF2 which resembles a transcriptional terminator (Fig. 2). Immediately downstream of this inverted repeat is a TTGGAA-16 bp-TATATT sequence which is a reasonable match to the -35 and -10 regions of the $\sigma^{70}$ promoter. Another stem-loop structure followed by a T-rich region was observed downstream of ORF2. This region may be a rho-independent transcription terminator. A PCR product representing the DNA region of ORF2 was inserted into pUC19 to investigate the expression of the predicted $\beta$-PGM gene. No $\beta$-PGM activity could be detected when a crude extract of strain JM83 harbouring the clone pNQ6 was investigated. However, a polypeptide with a molecular mass of $29 \mathrm{kDa}$ was detected by Western blot analysis. The lack of activity is probably due to a fusion between $\beta$-PGM and $\beta$-galactosidase. To prove that ORF2 is identical to the $\beta$-PGM polypeptide, $\beta$-PGM from $L$. lactis 19435 was purified to an extent that allowed its $\mathrm{N}$-terminal amino acid sequence to be determined. The sequence of the first 15 amino acid residues of the $\beta$-PGM polypeptide was -MFKAVLFXLXGVITX-. Except for three unidentified amino acid positions $(\mathrm{X})$, this sequence corresponded to the deduced $\mathrm{N}$-terminal amino acid sequence of ORF2, and we concluded that ORF2 is the lactococcal $\beta$-PGM gene, designated $\operatorname{pgmB}$.

An amino acid sequence homology search of available databases showed that the pgmB product has the highest identity $(27.6 \%)$ with a hypothetical protein from Mycobacterium leprae (GenBank accession no. U00015). A short sequence at the $\mathrm{N}$-terminus of $\beta$-PGM and the corresponding region of the unknown $\mathrm{Myco-}$ bacterium protein showed similarity with several metal- 


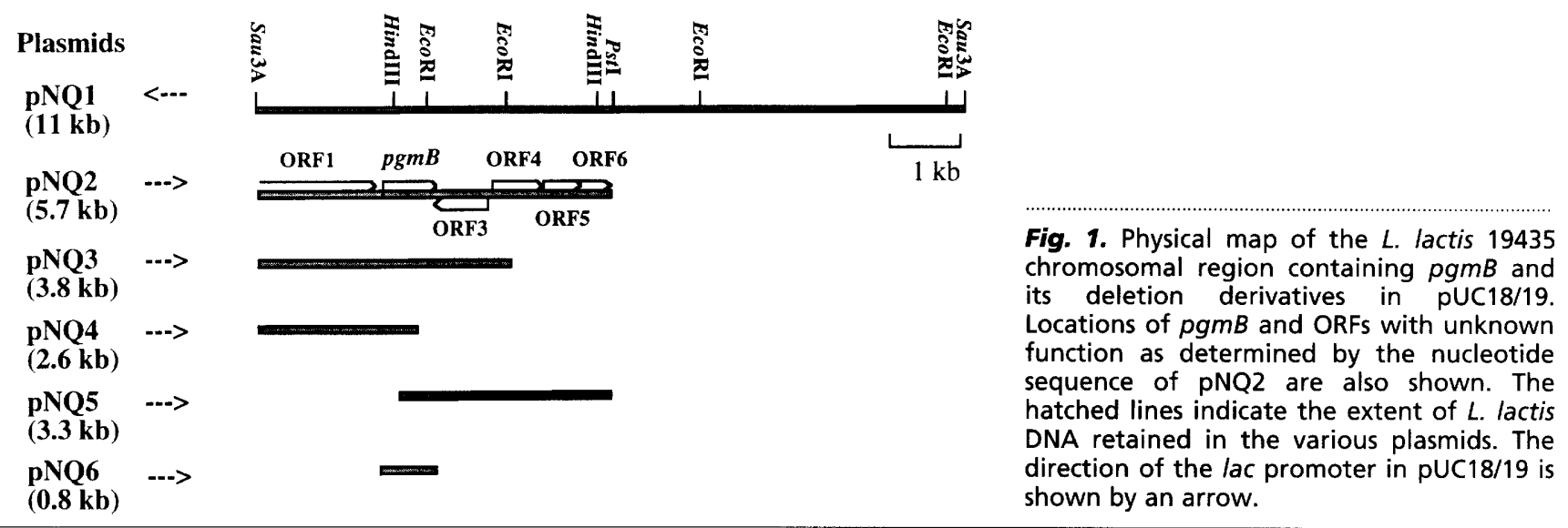

Table 2. Specific activity of $\beta$-PGM in L. lactis and in E. coli harbouring various plasmids

\begin{tabular}{|lccc|}
\hline Strain & $\begin{array}{c}\text { IPTG } \\
\text { addition* }\end{array}$ & $\begin{array}{c}\text { Specific } \\
\text { activity } \\
\left(\mathbf{U ~ m g}^{-1}\right) \dagger\end{array}$ & $\begin{array}{c}\text { Western } \\
\text { blot } \\
\text { result } \neq\end{array}$ \\
\hline E. coli JM83 & - & 0.002 & - \\
E. coli JM83 with pUC19 & - & 0.002 & - \\
E. coli JM83 with pNQ1 & + & $<0 \cdot 001$ & - \\
E. coli JM83 with pNQ2 & - & 0.032 & + \\
E. coli JM83 with pNQ3 & - & 0.028 & + \\
E. coli JM83 with pNQ4 & + & 0.044 & + \\
E. coli JM83 with pNQ5 & + & $0 \cdot 115$ & + \\
E. coli JM83 with pNQ6 & + & 0.054 & + \\
L. lactis ATCC 19435 & + & 0.108 & + \\
E. coli LE392 & Maltose & $<0.001$ & - \\
\hline
\end{tabular}

" + , IPTG $\left(0.5 \mathrm{mmol} \mathrm{m}^{-1}\right)$ was added to the growth medium; -, growth medium without IPTG.

† Specific activity of $\beta$-PGM measured after 10 h growth.

$\neq+$, Positive immunodetection of the $25 \mathrm{kDa} \beta$-PGM polypeptide; - , no visible polypeptide after immunostaining; $+^{\mathrm{a}}$, positive immunodetection of a $29 \mathrm{kDa}$ polypeptide.

binding proteins in the databases (Fig. 3). This hydrophobic-residue-rich region shows similarity to the -DGDGD- metal-ion-binding loop of $\alpha$-PGMs revealed by structural studies (Dai et al., 1992). The highly conserved catalytic site of $\alpha$-PGMs and phosphomannomutases was however not found in $\beta$-PGM. The deduced amino acid sequences of the other ORFs did not show any homology with the polypeptides in the databases. The incomplete ORF1 upstream of $p g m B$ is predicted to encode a polypeptide with more than 620 amino acids.

\section{Regulation of $\alpha$ - and $\beta$-PGM}

Previous work has shown that the synthesis of $\beta$-PGM is induced by maltose and repressed by glucose in the growth medium (Qian et al., 1994). The effect of maltose concentration on cell growth, product formation and $\alpha$ and $\beta$-PGM specific activity was investigated further. The exponential growth rate decreased once the initial maltose concentration was less than $5 \mathrm{~g} \mathrm{l}^{-1}$ (Fig. 4a); the specific growth rate decreased by factors of approximately $3.5\left(1.5 \mathrm{~g}\right.$ maltose $\left.\mathrm{l}^{-1}\right)$ and $7\left(0.8 \mathrm{~g}\right.$ maltose $\left.\mathrm{l}^{-1}\right)$. The maximum specific activity of $\beta$-PGM was around $0.20 \mu \mathrm{mol}$ NADPH (mg protein) ${ }^{-1} \mathrm{~min}^{-1}$ for both cultures containing initial maltose concentrations of $5 \cdot 5$ and $11.0 \mathrm{~g} \mathrm{l}^{-1}$ (Fig. $4 \mathrm{~b}$ ). $\beta$-PGM responded differently in the cultures containing 1.5 and $0.8 \mathrm{~g}$ maltose $1^{-1}$, reaching maximum specific activities of around 0.05 and $0.04 \mu \mathrm{mol}$ NADPH (mg protein $)^{-1} \mathrm{~min}^{-1}$, respectively. The specific activity of $\alpha$-PGM responded similarly to $\beta$ PGM, but the magnitude of the response was lower (Fig. 


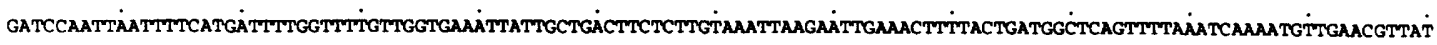
CGGGCTTTTGATAGTAAAGAATTTGAAGTAACAAAAATTTCCAAAGGACTTTTGGTTGCTAAAACAAGAACAAGTGAAATTGAACTTGCAATTGCTTCTAAATCATTTTTGGAATGGATTG̈

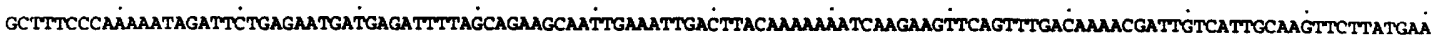

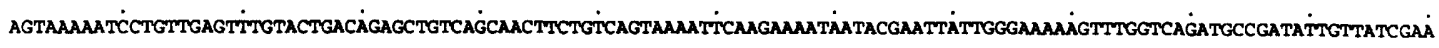
TCAGACCATGAAGATTTACAAAGAATGGTCAGGATGAACATTTTCCATATTCGTCAAGCGGCACAGCATGGTGCTAMTCAGTTTTTAGATGCATCAGTAGGTTCACGTGGCTTGACTGGT GAAGGTTATCGGGGTCATATCTTCTGGGATGAAATTTTTG̈TTCTTCCTTACTATGCGGCTAATGAGCCAGAAACGGCGCGTGATTTGCTTTTTGTACCGAATCAATCGATTGACCGCAGCG CAGGAAAATG̈GGAGGTTGATGGAGAMAiGGAGCTATGTTTCCTTGGCAGTCCGGCTTAMTTGGTGATGAACAATCGCAMTTTGTTCATTTGAACACA GTAAATAATGAATGGGAACCÄ

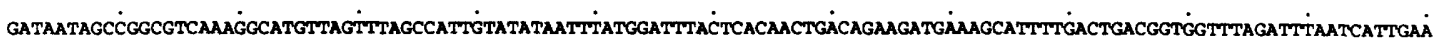
ACGACAAAGTTTTGGTTAAMTAMAGCCGAiTTAGGAGATGACGGCCGTTATCATATTGATGGGGTCATGGGACCTGATGAATATCATGAGGCCTATCCTGGGCAAGAAGGGGGAATCTGT

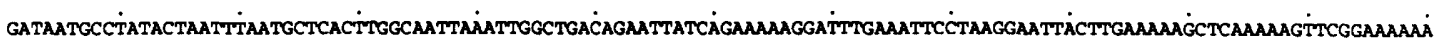

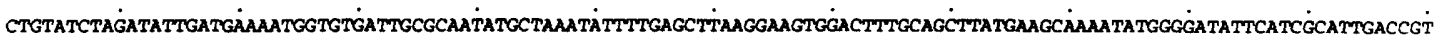
TTGATGAAGGCCGAAGGTATTTTCCCCTGACGAATATCAAGTGGCTAAACiGGCTGATACGCTGATGTTAATCTACAATTTGGGTCAGGAGCATGTGACTÄAGTTGGTCAAACAATTGGCT TATGAGTTGCCCGAAAATTGGTTGAAAGTCAACCGTGATTATTATCTTGCTAGGACTGTTCACGGTTCAACGACTTCACGTCCGGTTTTTGCTGGGATTGATGTGAAATTAGGGGATTTT GATGAAGCGTTGGATTTCTTGATTACAGCAATTGGCAGTGATTATTATGATATTCAAGGGGGAACAACGGCCGAAGGGGTTCATATTGGGGTCATGGGCGAAACGCTCGÄGGTGATTCAÄ

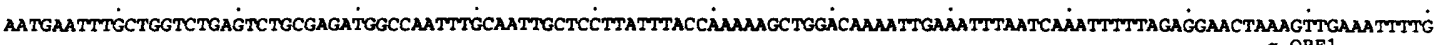
ATTGAAAATGGGACAATTAT'TACTGACAGCǴTCGGCGGATTTACTGACCAAAGTTTATGATGATCAGGTTCAATTAAAAGCCGGAGTGCAGACTAAATTTGA GTTTAAAATAAATGGTTTTA

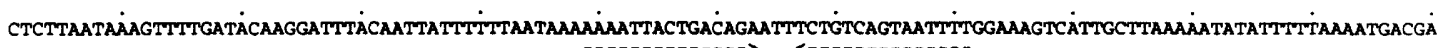

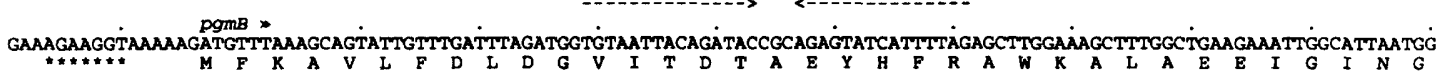

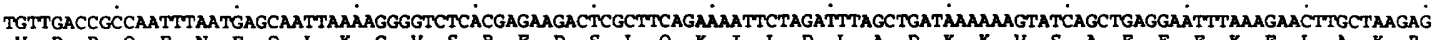

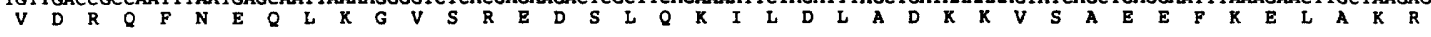
AAAAATGATAACTATGTGAAAATGATTCAGGATGTGTCG்CCAGCCGATGTCTATCCTGGATTTTACAATTACTCAAAGATTTACGTTCAAATAAATCAAAATTGCTTTAGCGTCGGC $\begin{array}{llllllllllllllllllllllllllllllllllllllllll}K & N & D & N & Y & V & K & M & I & Q & D & V & S & P & A & D & V & Y & P & G & I & L & Q & L & L & K & D & L & R & S & N & K & I & K & I & A & L & A & S & A\end{array}$

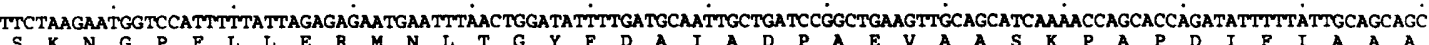

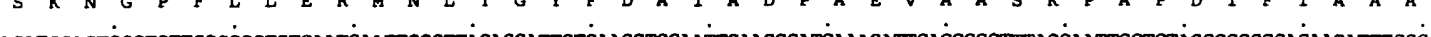

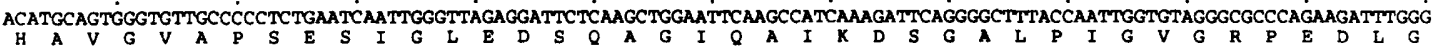

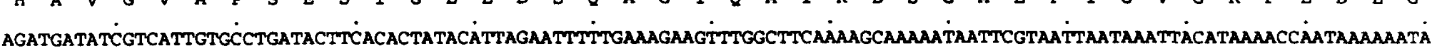
$\begin{array}{llllllllllllllllllllllllll}D & D & I & V & I & V & P & D & T & S & H & Y & T & L & E & F & L & K & E & V & W & L & 0 & K & 0 & K\end{array}$

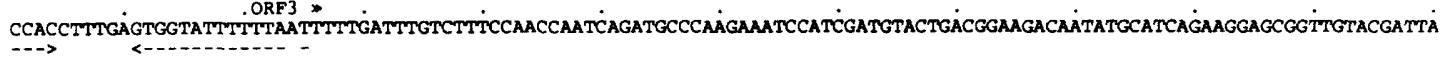

GCCAAAGAGäCACCATGAGGTCCAGATTCAAAAAAGTGAGCTTCAAAAGGAACTTGATGTTTTGAGAGTĆGATCACAATATTTAAGGCTG'TTATAGATAGGAACACCCTCATCATCAGCC

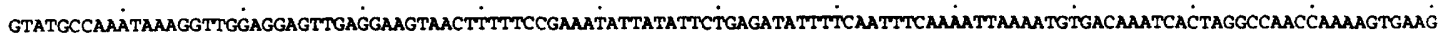
GAAGTTACTGGGATAGCAGAGAATAACTCCTTTTGGTCGATGGATTTGTTCAGAATTACCATACCAAGCGGCCAGATGCCC̈TCCGGCAGAGCAACCAAGTAAGAAAACTTGCTCAGGATTG ATTTGCCATTCTTTATGATTTTGATGAATCAGAGAAAAACAGCTTGAACTTCTTCAAGATTTTGTGATAAAAAGTTATÁGTTTGTTCCITTGTTCATCACGGTGTAATTAAGGAGAAGC ACTTGATAACCTTTGGGGAGAAAGGCTAAGGCAAGAGGGTCAGATTCTCTTTGTGAAATATGTTGATAACCACCACCAGGGCAGATAATAATAGCAGGAAAAGTATAATITTTCGTTTTGÄ

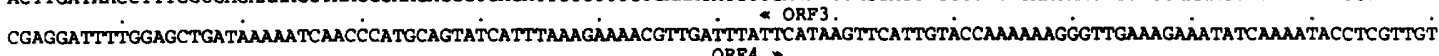

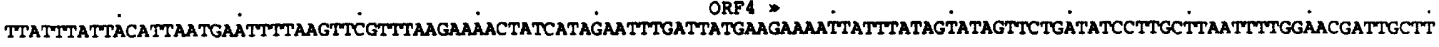

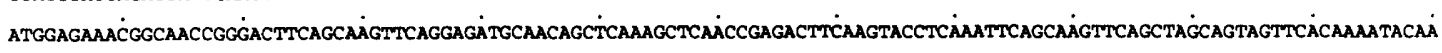

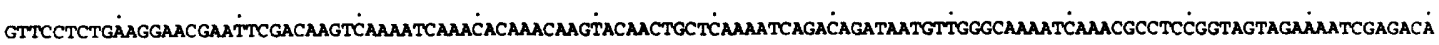
GTTCAACAGÄTAAAAATTCTGGCAGTCAAiAaGAAACTAAAAATTCAACCACAATTATTAATGAAACCGTCAACAATAATGCCAAGGGGAACAATATTCT'TTTGATGACATTGACCAGTT

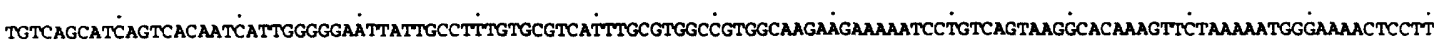

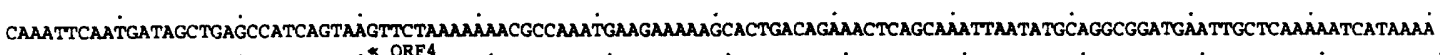

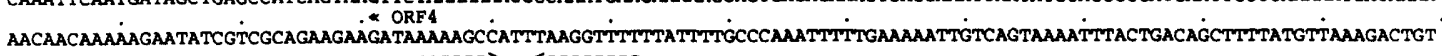

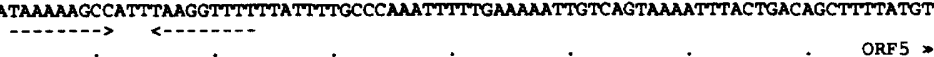
GATAATGTAGGAGATAAACTTTTTGAAGTGGCAACACTGGAaTTTTCTMMGGTTTGACTATTTTTAGATTCATCAGTTGCAMACGTTAGATAGTGTCTTAGGGGATGTGTTATAATAAAÄ

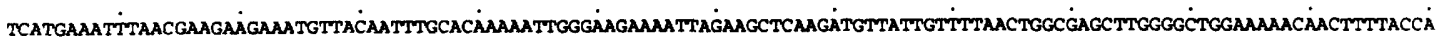

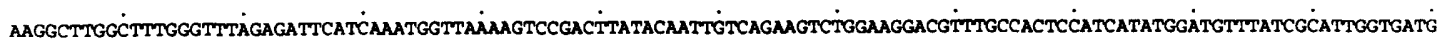
ATCCGGATAG̈TTTTGATTTAGATGATTATTTATTCGGTGATGGGGTTTCGGTCATTGAATGGGGCGAATGGTTAGGCGA GGATTTGCCAGAAAATTATCTGGAAGTCATTTTTGATAAGT

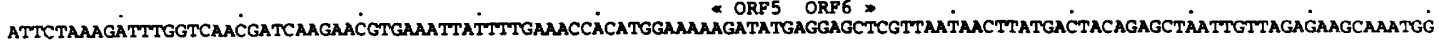
CGCCGACAGTTCTAGAGTCA'TTGAATTTCTCAATAMGGTTGGAACAGAMi GTAATTTTTTGGACCATTGATGAAGTAGGAiTTTTAATCTCTGAAGCAGAAATGACGGACTTTTTAAATCA ACAGGCTGAGAAAGATAATAATGCTTATTTTCTTGCATTCGTTGGTGATGAAATTGCTGGTATTTTGCATTTTGCGGCGGATTATCATTATCGAGTACGTCATATTGCGGAACTTTTTAT

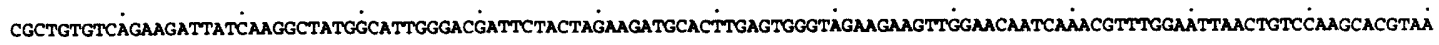

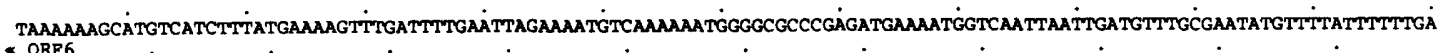

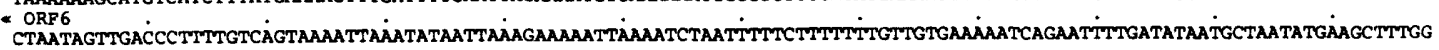

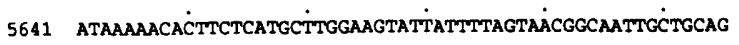

Fig. 2. Nucleotide sequence of the 5695 bp Sau3A-Pstl fragment and the deduced amino acid sequence of pgmB. The putative ribosome-binding site is marked by asterisks. Three stem-loop structures are indicated by horizontal arrows under the sequence. Five ORFs (ORF1, 3, 4, 5 and 6) are marked above the start and stop codons. 


\begin{tabular}{|c|c|c|c|c|c|}
\hline Organism & Protein & Amino acid sequence & Pos & Func & Reference \\
\hline & & FKAVLFDLDGVITDTAE & 8 & PT & This study \\
\hline & $\alpha-$ PGM & DFGAAFDGDGDRNMILG & 287 & PT & DORO \\
\hline N.go & $\alpha-$ PGM & EIGLAFDGDADRLGVVT & 239 & PT & P40390 \\
\hline s.ce & PMM & ETLVLFDVDGTLTPARL & 19 & PT & P07283 \\
\hline C.al & PMM & KTLVLFDVDGTLTPARL & 15 & $\mathrm{PT}$ & P31353 \\
\hline $\mathrm{Rab}$ & $\mathrm{CP}$ & FKTLDTDLDGVVTFDLF & 301 & Hy & 0681 \\
\hline Hum & $C P$ & FKTLDTDLDGVVTFDLF & 297 & $\mathrm{H}$ & 3 \\
\hline BPT 4 & PK & PKAVIFDVDGTLAKMNG & 165 & $\mathrm{PT}$ & P06855 \\
\hline s.ce & $2 \mathrm{D} 6 \mathrm{PP}$ & ADLCLFDLDGTIVSTTV & 12 & Hy & U03107 \\
\hline P.no & $\mathrm{PL}$ & FNGILFDLDKSQNDIAS & 353 & $\mathrm{Hy}$ & P39457 \\
\hline M.le & $\mathrm{T} 6 \mathrm{PP}$ & HSAALFDLDAVVTDTPL & 16 & Hy & U00015 \\
\hline Rat & PTK & FRAILRDLNGLITSDYE & 987 & PT & L33768 \\
\hline A. eu & $\mathrm{PP}$ & CTAVI & 14 & 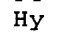 & \\
\hline Hum & $\mathrm{CEH}$ & LRGAVFDL DGVLAL PAV & 9 & Hy & P34913 \\
\hline Ps & $2 \mathrm{HAD}$ & IRGVVFDLYGTLCDVHS & 10 & Hy & P24070 \\
\hline Rat & $\mathrm{CEH}$ & LRVAAFDLDGVLALPSI & 8 & Hy & \\
\hline $\mathrm{x} . \mathrm{au}$ & $\mathrm{HAH}$ & IKAT & 8 & $\mathrm{HY}$ & $\mathrm{m}$ \\
\hline A.eu & hypo & MQALIFDVDGTLADTES & 7 & ? & $\mathrm{m} 64173$ \\
\hline H. in & hypo & YEGLIFDMDGTL IDTMP & 16 & ? & U32731 \\
\hline M.le & hypo & VRACLFDLDGVLTDTAS & 28 & ? & U00015 \\
\hline L.ca & hypo & TATVIFDLD & 8 & $\cdot$ & P35924 \\
\hline E.co & hypo & IRGVAFDLDC & 13 & ? & S31740 \\
\hline S.fr & hypo & ARAVVFDTDGVLTDSAR & 27 & ? & D. \\
\hline S.ce & hypo & IKAVVFDMDGTLCLPQP & 18 & ? & X90518 \\
\hline B.su & hypo & FDVFLFDLDGVIYVGPE & 11 & $\therefore$ & P46351 \\
\hline & GS & PKVILFDLDSVRGYSNE & 104 & GT & P27472 \\
\hline \multirow[t]{2}{*}{ C.el } & TO & FKQIIFDLDNVRKLLNN & 86 & $\mathrm{OR}$ & Q09474 \\
\hline & & & & & \\
\hline
\end{tabular}

Fig. 3. Sequence alignment between the $\mathrm{N}$-terminal amino acid sequence of $\beta$-PGM and 26 other known and presumed metalbinding proteins. Amino acid positions with 17 or more identical residues are shown as a consensus sequence in bold letters. Organisms: L.la, L. lactis; Rab, rabbit; N.go, Neisseria gonorrhoeae; S.ce, Saccharomyces cerevisiae; C.al, Candida albicans; Hum, human; BPT4, bacteriophage T4; P.no, Penicillium notatum; M.le, Mycobacterium leprae; A.eu, Alcaligenes eutrophus; Ps, Pseudomonas sp; X.au, Xanthobacter autotrophicus; H.in, Haemophilus influenzae; L.ca, Lactobacillus casei; E.co, Escherichia coli; S.fr, Streptomyces fradiae; B.su, Bacillus subtilis; C.el, Caenorhabditis elegans. Proteins: $\quad \alpha$-PGM, $\alpha$-phosphoglucomutase; PMM, phosphomannomutase; $\mathrm{CP}$, cysteine protease; PK, polynucleotide kinase; 2D6PP, 2-deoxyglucose-6-phosphate phosphatase; PL, phospholipase; T6PP, trehalose-6-phosphate phosphatase; PTK, protein-tyrosine kinase; PP, phosphoglycolate phosphatase; $\mathrm{CEH}$, cytosolic epoxide hydrolase; 2HAD, 2-haloalkanoic acid dehalogenase II; $H A H$, halocarboxylic acid halidohydrolase; hypo, hypothetical protein; GS, glycogen synthase; TO, tryptophan oxygenase. Pos, numbering is based on the distance from the first amino acid to the absolutely conserved Asp. Func, function of the proteins; PT, phosphotransferases; Hy, hydrolase; ?, unknown function; GT, glycosyltransferase; OR, oxidoreductase.

4b). A mixed acid formation was observed in all cultures (data not shown), but there was an increase in the amount of lactate produced relative to the other products when the initial maltose concentration in the medium was increased. Fig. 5 shows the ratio of the change in lactate concentration $\left(\mathrm{mmol} \mathrm{l}^{-1}\right)$ to the change in total product (lactate, formate, acetate, ethanol) concentration $\left(\mathrm{mmol} \mathrm{l}^{-1}\right)$, against time. A ratio greater than 1 occurred near the end of some fermentations due to a slight decrease in the concentrations of formate, acetate and ethanol; this resulted in negative values for the concentration change of these products.

The effect on $\beta$-PGM expression by sugars other than maltose and glucose was investigated by inoculating $L$. lactis 19435 into defined media containing different
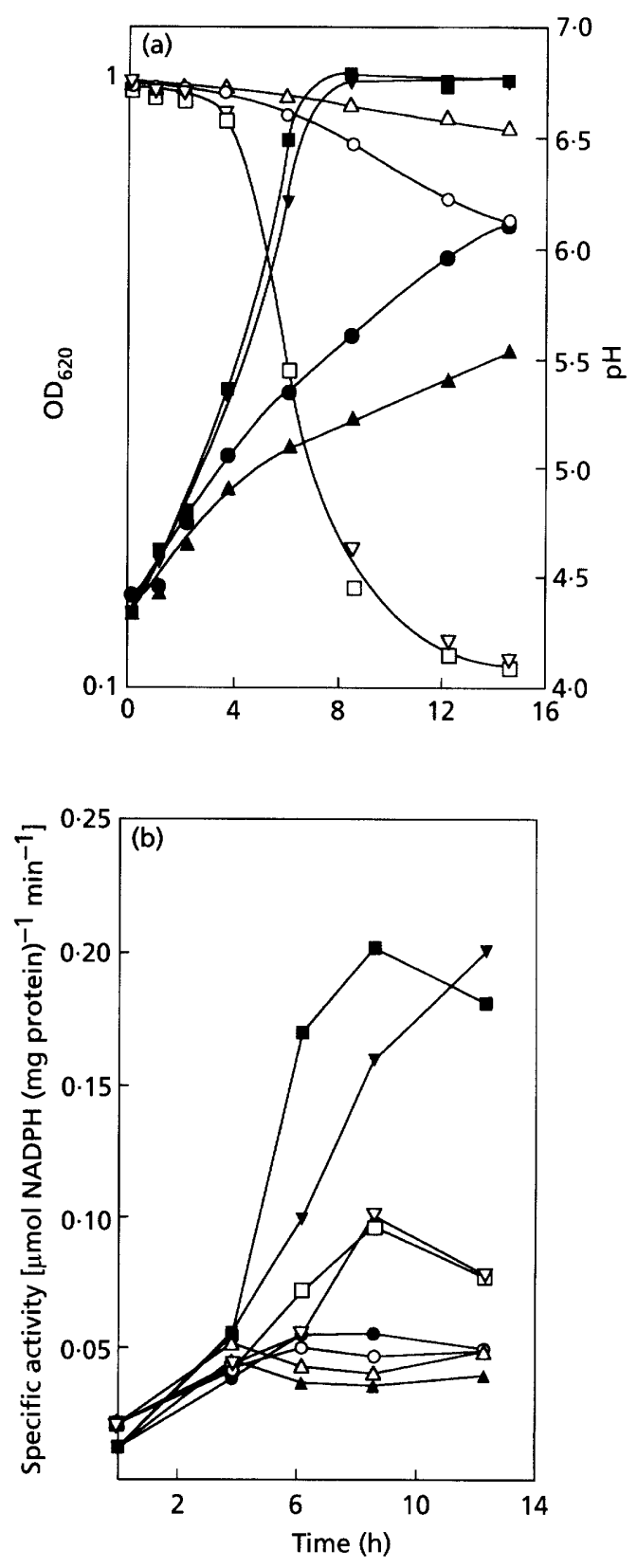

Fig. 4. Effect of maltose concentration on (a) growth (filled symbols) and $\mathrm{pH}$ (open symbols) and (b) the specific activity of $\alpha$-PGM (open symbols) and $\beta$-PGM (filled symbols) of $L$. lactis 65.1. Initial maltose concentrations in $\mathrm{g} \mathrm{I}^{-1}$ were: $0.8(\Delta, \Delta), 1.5$ $(\bullet, 0), 5.5(\nabla, \nabla)$ and $11.0(\square, \square)$.

sugars and measuring cell growth and $\beta$-PGM specific activity after $10 \mathrm{~h}$ incubation (Table 3 ). The activity was induced by trehalose and sucrose in the medium. The $\beta$ PGM specific activity of trehalose-grown cells was over three times greater than that measured in maltose- and sucrose-grown cells. After $10 \mathrm{~h}$, cultures containing trehalose had the highest cell yield, sucrose cultures had the lowest cell yield and lactose, maltose, mannose and glucose cultures grew to approximately the same optical density. 


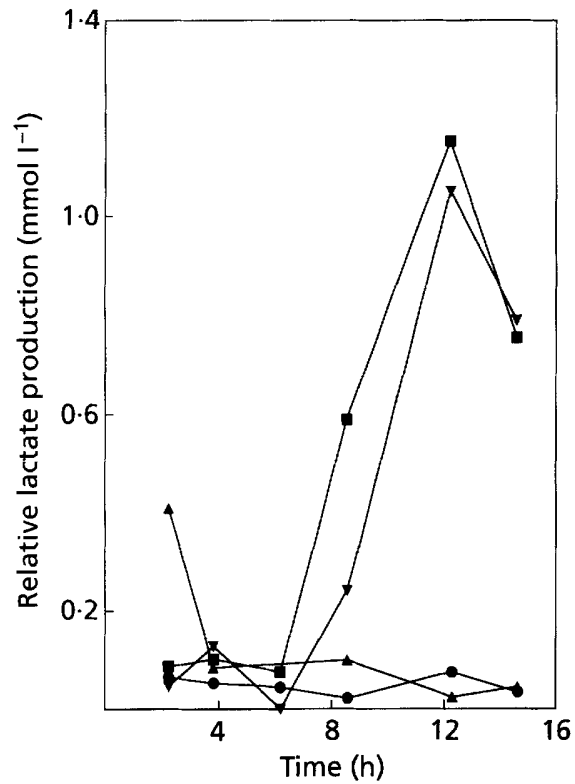

Fig. 5. Effect of maltose concentration on relative lactate formation by $L$. lactis 65.1 . Relative lactate formation is defined as the ratio of the change in lactate concentration $(\mathrm{mmol})$ to the sum of the changes in concentration of lactate, formate, acetate and ethanol ( $\mathrm{mmol}$ ) during the time period between each sample set. Initial maltose concentrations in $\mathrm{g} \mathrm{I}^{-1}$ were: 0.8 $(\Delta), 1.5(\mathbf{O}), 5.5(\nabla)$ and $11.0(\mathbf{D})$.

Table 3. Effect of different carbohydrate sources on cell growth and activity of $\beta$-PGM in L. lactis

\begin{tabular}{|lrr|}
\hline Carbon source & $\mathrm{OD}_{600}$ & $\begin{array}{c}\text { Specific } \\
\text { activity*" }\end{array}$ \\
\hline Glucose & 1.38 & $<0.001$ \\
Maltose & 1.41 & 0.428 \\
Trehalose & 2.06 & 1.388 \\
Lactose & 1.40 & $<0.001$ \\
Sucrose & 0.63 & 0.446 \\
Mannose & 1.42 & $<0.001$ \\
\hline
\end{tabular}

* Specific activity $\left(\mathrm{U} \mathrm{mg}^{-1}\right)$ of $\beta$-PGM measured after $10 \mathrm{~h}$ growth.

\section{The effect of mixed sugar substrates on L. lactis growth, product formation and phosphoglucomutase activity}

The growth curves from the experiments containing substrate mixtures of maltose and glucose (Fig. 6a), and maltose and lactose (Fig. 6c), demonstrate that L. lactis cannot catabolize the carbohydrates in these substrate mixtures concurrently. Glucose (Fig. 6b) or lactose (Fig. $6 \mathrm{~d})$ are used in preference to maltose, which is only utilized after glucose or lactose has been exhausted (Fig. $6 \mathrm{~b}, \mathrm{~d})$; a long diauxic growth lag period is a feature of these fermentations (Fig. 6a, c). Product formation switches from homolactic during growth on glucose (Fig. 6b) or lactose (Fig. 6d) to a mixed product formation during growth on maltose. $\beta$-PGM specific activity was low during growth on glucose or lactose (Fig. 6a, c), but it increased when these sugars were exhausted and maltose was the only carbohydrate present; this may account for the inability of L. lactis to use maltose when glucose or lactose are present. $\alpha$-PGM followed the same trend as $\beta$-PGM.

A different fermentation pattern was observed when a substrate combination of galactose and maltose (Fig. 6e, f) was used. The diauxic growth lag period was absent (Fig. 6e) and galactose and maltose were used concurrently (Fig. 6f). The specific activities of $\alpha$ - and $\beta$ PGM increased even in the presence of galactose (Fig. 6e) and $\beta$-PGM attained a much higher maximum specific activity compared to the fermentations using substrate combinations of maltose with either glucose (Fig. 6a) or lactose (Fig. 6c). The apparent lack of an inhibitory effect of galactose on $\beta$-PGM activity may explain why lactococci can catabolize maltose and galactose concurrently.

The above experiment which used a substrate mixture of glucose and maltose (Fig. 6a, b) contained a relatively low concentration of maltose $\left(1 \cdot 1 \mathrm{~g} \mathrm{l}^{-1}\right)$. The maximum $\beta$-PGM specific activity attained by this mixed substrate culture (Fig. 6a) reflects the relatively low maximum $\beta$ PGM specific activity achieved when similar maltose concentrations were used in the single substrate experiments (Fig. 4a, b). The fermentations in Fig. 4 demonstrated that high maltose concentrations induce a higher activity of $\beta$-PGM (Fig. 4b). Given the dependence of $\beta$ PGM activity on maltose concentration, it was possible that a stronger induction of $\beta$-PGM by a higher maltose concentration may be sufficient to negate the repression of $\beta$-PGM expression by glucose in mixed substrate fermentations. As shown in Fig. $6(\mathrm{~g})$, a higher maltose concentration $\left(20 \mathrm{~g} \mathrm{l}^{-1}\right)$ resulted in the absence of a diauxic growth lag period and higher maximum $\alpha$ - and $\beta$-PGM specific activities, but the activity of $\beta$-PGM was still repressed during the time glucose was in the culture (Fig. 6g, h). The most surprising feature is that substantial quantities of maltose were consumed while glucose was present (Fig. 6h), even though the $\beta$-PGM specific activity was low during this period (Fig. $6 \mathrm{~g}$ ). This is in contrast to the previous experiment containing glucose and low concentrations of maltose (Fig. 6a, b), since maltose was not consumed while glucose was still present in the culture.

\section{DISCUSSION}

$\alpha$-PGM and $\beta$-PGM catalyse the reversible reaction between glucose 1-phosphate and glucose 6-phosphate in the presence of catalytic amounts of glucose 1,6diphosphate and a divalent metal ion. Although the two PGM enzymes in lactococci only differ in the specificity of the phosphate group at the anomeric carbon atom of glucose, our work has demonstrated that there are considerable differences in their enzymic structures and in their metabolic functions.

PGM enzymes with $\alpha$-specificity contain two highly conserved amino acid regions (Dai et al., 1992; Ray \& 


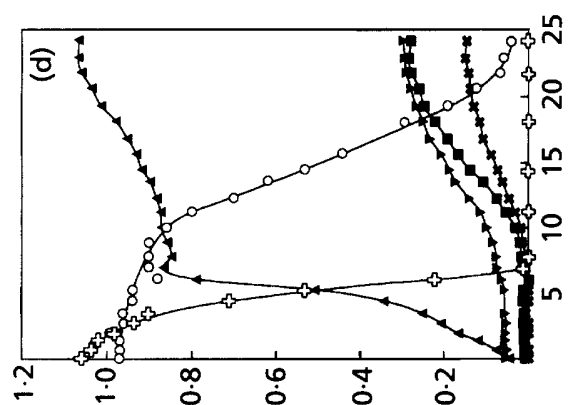

(L-1 6) słonposd 'səjejzsqns
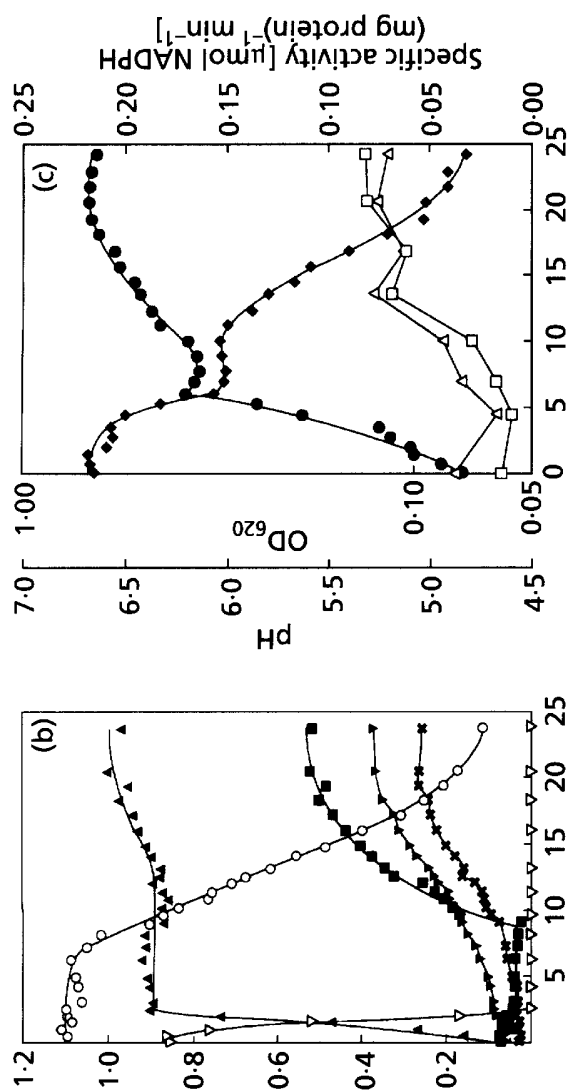

${ }_{(1-1}$ 6) słonposd 'səłedzsqns

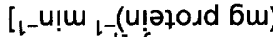

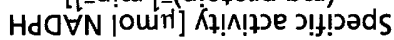
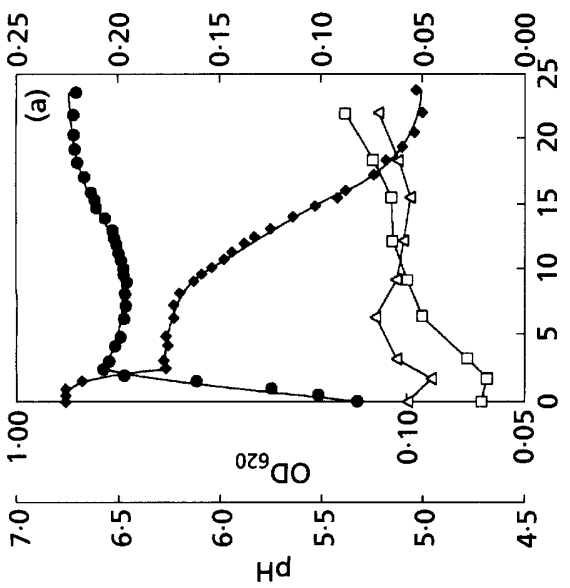

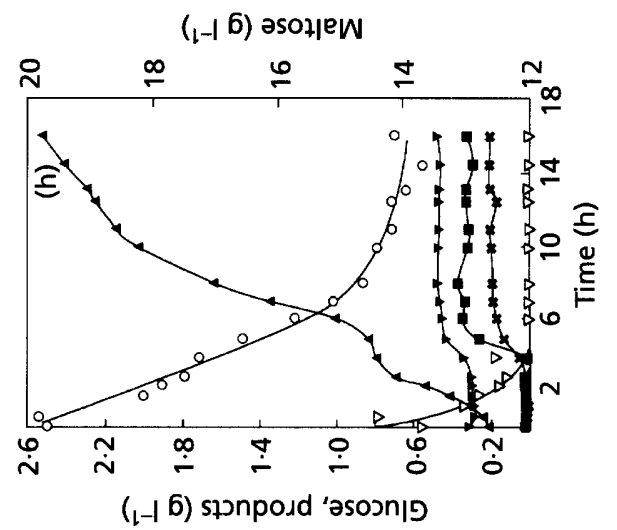

[_-U!m ,_(uाәtodd $6 m$ )

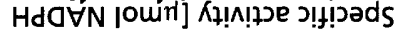
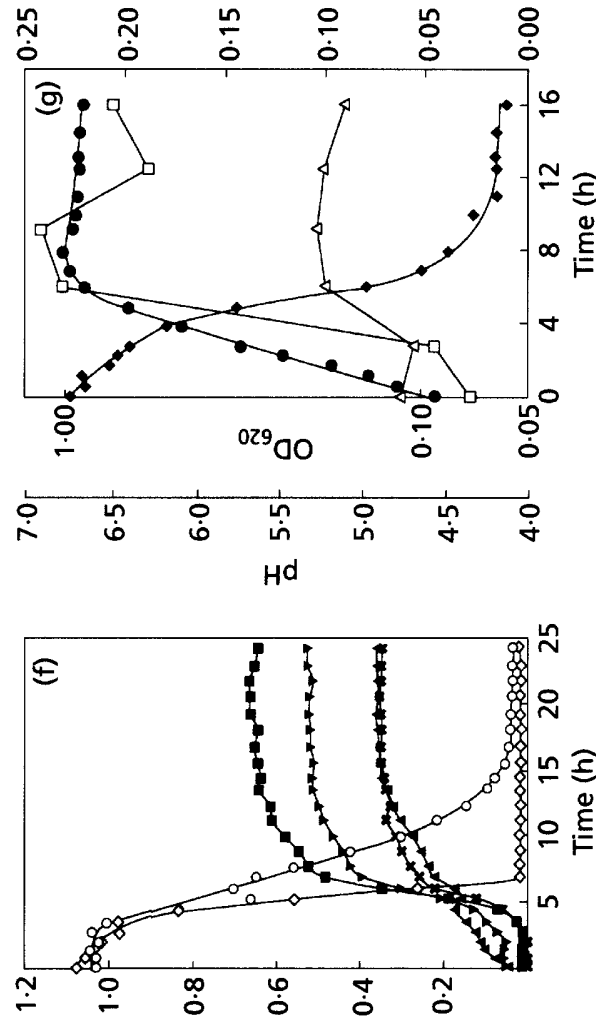

${ }_{(1-1}$ 6) słonposd 'səzedzsqns

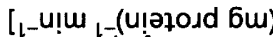

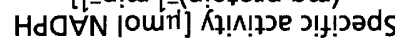

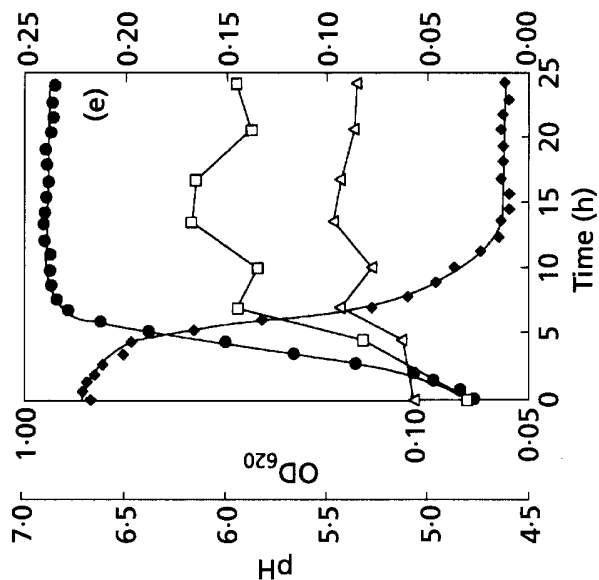

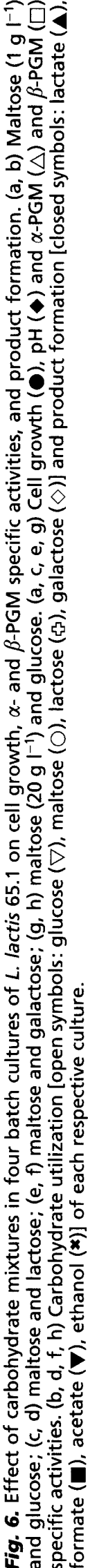


Peck, 1972). These regions, a catalytic domain, $\mathrm{G}(\mathrm{I} / \mathrm{V})(\mathrm{V} / \mathrm{I})(\mathrm{I} / \mathrm{L}) \mathrm{T}(\mathrm{P} / \mathrm{A})$ SHNP-, and a metal-ion-binding motif,-DGDGD-, are situated in the active site of the enzyme. A third region of homology was recently reported to be present in three PGM enzymes with phosphoglucose specificity (Brautaset et al., 1994). It was suggested that enzymes lacking this third motif may have a broader substrate specificity. The deduced amino acid sequence of $\operatorname{pgmB}$ has no obvious similarity with the conserved regions of $\alpha$-PGM. However, the $\mathrm{N}$ terminal amino acid sequence of $\beta$-PGM was found to contain a region, -FDLDGV-, with homology to the $\mathrm{Ca}^{2+}$-binding site -DTDLDGVVTFDLF- of human and rabbit cysteine proteases (Minami et al., 1987; Sorimachi et al., 1990) as well as the $\mathrm{Mn}^{2+}$ - and $\mathrm{Mg}^{2+}$ binding site -DGDGD- of $\alpha$-PGMs (Fig. 3). A human inositol monophosphatase and a bovine inositol-polyphosphate 1-phosphatase have a similar conserved sequence, -DPIDGT-(Bone et al., 1994). It was suggested that these phosphatases form a structural family with a conserved metal-binding site. Fig. 3 shows a consensus sequence, -FDLDG-, based on an alignment of several phosphotransferases, hydrolases and a number of hypothetical proteins. This motif is located at the $\mathrm{N}$ terminus in 21 of 27 polypeptides investigated. Thus, the sequence -FDLDGV- may be a metal-binding site of $\beta$ PGM. Furthermore, the alignment of the amino acid sequences of the proteins in Fig. 3 (data not shown) showed another conserved amino acid region, $\mathrm{KP}(\mathrm{A} / \mathrm{D}) \mathrm{P}-$, in 12 of the proteins (Fig. 3), which strengthens the relationship among them.

The expression of $\beta$-PGM was found to be induced by the disaccharides maltose (Qian et al., 1994), trehalose and sucrose, which share an $\alpha$-D-glucopyranosyl structure. These disaccharides are probably phosphorylated to $\beta$-D-glucopyranosyl phosphate and glucose by one or several disaccharide phosphorylases. This indicates that $\beta$-D-glucopyranosyl phosphate, or its derivatives, may be the inducer of $\beta$-PGM. Furthermore, the presence of $\beta$-PGM activity in the catabolism of these disaccharides suggests that $\beta$-PGM does not serve solely to degrade maltose, but that it is also involved in the metabolism of other sugars. $\alpha$-PGM appears to follow a similar pattern to $\beta$-PGM in the presence of different carbohydrates. However, the magnitude of the change in its activity is not as great. The mechanism of regulation of $\alpha$-PGM is not known in lactococci, but an induced $\alpha$-PGM has been described in Saccharomyces cerevisiae when glucose repression is relieved or when galactose replaces glucose as the primary carbon source (Oh \& Hopper, 1990). These results indicate that the activities of $\alpha$ - and $\beta$-PGM in lactococci play a key role in the regulation of the flow of carbohydrate intermediates in glycolysis and the formation of the sugar nucleotide UDPglucose.

The diauxic lag periods observed in the mixed substrate experiments appear to be a result of the weak induction of maltose catabolic enzymes by low maltose concentrations. This is evident by the slow rise in $\beta$-PGM specific activity in the presence of low maltose concentrations after glucose exhaustion, which contrasts with the absence of a growth lag period and corresponding rapid rise in $\beta$-PGM specific activity after glucose expiration when a high concentration of maltose was used. The poor induction of $\beta$-PGM activity by low maltose concentrations, and corresponding low growth rates, was also demonstrated in single substrate experiments using maltose at various initial concentrations. It is almost certain that $\beta$-PGM is not the only enzyme responsible for the effect of maltose concentration on Lactococcus growth, but its response to various maltose concentrations is likely to reflect the changes in activity of all maltose-specific catabolic enzymes in L. lactis, since previous work indicates that the maltose permease and phosphorylase are affected by maltose and glucose in a similar way to $\beta$-PGM (Citti et al., 1966; Sjöberg et al., 1995). Preferential sugar utilization has previously been observed in lactococci (Thompson, 1987) using glucose, lactose and galactose. It was later found that the preferred sugars, glucose and lactose, prevented galactose uptake by both inducer exclusion and inducer expulsion mechanisms (Thompson \& Saier, 1981). These mechanisms, and also catabolite inhibition and catabolite repression (Magasanik \& Neidhardt, 1987), are associated with an active phosphoenolpyruvate sugar phosphotransferase (PEP-PTS) transport system which can inhibit the utilization of sugars not transported by a PTS system (Saier et al., 1996). Like galactose, maltose catabolism in lactococci appears to be repressed by PEP-PTS transport since glucose and lactose, both of which are transported by PEP-PTS systems in L. lactis (De Vos et al., 1990; Thompson, 1980), prevented maltose uptake and suppressed $\beta$-PGM activity at low maltose concentrations. Galactose, which at low concentrations is transported by a permease system in lactococci (Thomas et al., 1980), did not inhibit maltose uptake. The particular mechanism(s) by which glucose and lactose inhibit the uptake of maltose by lactococci cannot be confidently deduced from our data. However, the low $\beta$-PGM activity during growth on glucose or lactose, and its increase following the exhaustion of these two sugars, suggest that it is associated with catabolite repression. Catabolite inhibition cannot account for the change in $\beta$-PGM specific activity, since we have previously demonstrated that the specific activity of $\beta$-PGM is related to the amount of $\beta$ PGM in the cell during growth on maltose and maltose/ glucose combinations (Qian et al., 1994).

Maltose concentration was also found to affect product formation in L. lactis cultures, which was less homolactic when the maltose concentration was low $(0.8$ and $1.5 \mathrm{~g} \mathrm{l}^{-1}$; Fig. 5). Mixed acid fermentations have also been observed in Lactococcus cultures grown on low galactose concentrations (Thomas et al., 1980). Under these conditions, galactose is transported by a highaffinity permease and initially metabolized by the Leloir pathway (Thompson, 1980). When the galactose concentration was increased, a low-affinity PEP-PTS dominated galactose transport and product formation became homolactic. In our mixed substrate experiments, maltose was consumed concurrently with glucose when 
the maltose concentration was high, even though $\beta$ PGM levels were low. This was not observed when the concentration of each sugar was low, which suggests that there may be two maltose transport systems in $L$. lactis with different maltose affinities, as is the case for galactose (Thomas et al., 1980; Thompson, 1980)

\section{ACKNOWLEDGEMENTS}

We gratefully acknowledge Bärbel Hahn-Hägerdal and Lars Rutberg for support and valuable discussions. We also thank Maria Mattsson for skilful technical assistance. This work was supported by a grant from the Swedish Council for Forestry and Agricultural Research.

\section{REFERENCES}

Ben-Zvi, R. \& Schramm, M. (1961). A phosphoglucomutase specific for $\beta$-glucose 1-phosphate. J Biol Chem 236, 2186-2189.

Bone, R., Frank, L., Springer, J. P. \& Atack, J. R. (1994). Structural studies of metal binding by inositol monophosphatase: evidence for two-metal ion catalysis. Biochemistry 33, 9468-9476.

Bradford, M. M. (1976). A rapid and sensitive method for the quantitation of microgram quantities of protein utilizing the principle of protein-dye binding. Anal Biochem 72, 248-254.

Brautaset, T., Standal, R., Fjaervik, E. \& Valla, S. (1994). Nucleotide sequence and expression analysis of the Acetobacter xylinum phosphoglucomutase gene. Microbiology 140, 1183-1188.

Citti, J. E., Sandine, W. E. \& Elliker, P. R. (1966). Lactose and maltose uptake by Streptococcus lactis. J Dairy Sci 50, 485-488.

Dai, J. B., Liu, Y., Ray, W. J. \& Konno, M. (1992). The crystal structure of muscle phosphoglucomutase refined at $2 \cdot 7$-angstrom resolution. J Biol Chem 267, 6322-6337.

De Vos, W. M., Boerrigter, I., van Rooyer, R. J., Reiche, B. \& Hengstenberg, W. (1990). Characterization of the lactose-specific enzymes of the phosphotransferase system in Lactococcus lactis. J Biol Chem 265, 22554-22560.

Fitting, C. \& Doudoroff, M. (1952). Phosphorolysis of maltose by enzyme preparations from Neisseria meningitidis. J Biol Chem 199, 153-163.

Frischauf, A. M., Lehrach, H., Poustka, A. \& Murray, N. (1983). Lambda replacement vectors carrying polylinker sequences. $J$ Mol Biol 170, 827-842.

Laemmli, U. K. (1970). Cleavage of structural proteins during the assembly of the head of bacteriophage T4. Nature 227, 680-685.

Ludwig, W., Seewaldt, E., Kilpper-Bälz, R., Schleifer, K. H., Magrum, L., Woese, C. R., Fox, G. E. \& Stackebrandt, E. (1985). The phylogenetic position of Streptococcus and Enterococcus. $J$ Gen Microbiol 131, 543-551.

Magasanik, B. \& Neidhardt, F. C. (1987). Regulation of carbon and nitrogen utilization. In Escherichia coli and Salmonella typhimurium: Cellular and Molecular Biology, pp. 1318-1325. Edited by F. C. Neidhardt, J. L. Ingraham, K. Brooks Low, B. Magasanik, M. Schaechter \& H. E. Umbarger. Washington, DC: American Society for Microbiology.

Maréchal, L. R. \& Belocopitow, E. (1974). Metabolism of trehalose in Euglena gracilis. Eur J Biochem 42, 45-50.

Maréchal, L. R., Oliver, G., Veiga, L. A. \& de Ruiz Holgado, A. A. P. (1984). Partial purification and some properties of $\beta$ phosphoglucomutase from Lactobacillus brevis. Arch Biochem Biophys 228, 592-599.

Minami, Y., Emori, Y., Kawasaki, H. \& Suzuki, K. (1987). E-F hand structure-domain of calcium-activated neutral protease (CANP) can bind $\mathrm{Ca}^{2+}$ ions. J Biochem 101, 889-895.

Moustafa, H. H. \& Collins, E. B. (1968). Role of galactose or glucose 1-phosphate in preventing the lysis of Streptococcus diacetilactis. J Bacteriol 95, 592-602.

Oh, D. \& Hopper, J. E. (1990). Transcription of a yeast phosphoglucomutase isozyme gene is galactose inducible and glucose repressible. Mol Cell Biol 10, 1415-1422.

Qian, N., Stanley, G. A., Hahn-Hăgerdal, B. \& Rådström, P. (1994). Purification and characterization of two phosphoglucomutases from Lactococcus lactis subsp. lactis and their regulation in maltose and glucose utilizing cells. J Bacteriol 176, 5304-5311.

Ray, W. J., Jr \& Peck, E. J., Jr (1972). Phosphomutases. In The Enzymes, 3rd edn, vol. 6, pp. 407-458. Edited by P. D. Boyer. New York: Academic Press.

Saier, M. H., Jr, Chauvaux, S., Cook, M. G., Deutscher, J., Paulsen, I. T., Reizer, J. \& Ye, J. (1996). Catabolite repression and inducer control in Gram-positive bacteria. Microbiology 142, 217-230.

Sambrook, J., Fritsch, E. F. \& Maniatis, T. (1989). Molecular Cloning: a Laboratory Manual, 2nd edn. Cold Spring Harbor, NY : Cold Spring Harbor Laboratory.

Sanger, F., Nicklen, S. \& Coulson, A. R. (1977). DNA sequencing with chain-terminating inhibitors. Proc Natl Acad Sci USA 74, 5463-5467.

Sjöberg, A. \& Hahn-Hăgerdal, B. (1989). $\beta$-Glucose-1-phosphate, a possible mediator for polysaccharide formation in maltoseassimilating Lactococcus lactis. Appl Environ Microbiol 55, 1549-1554.

Sjöberg, A., Persson, I., Quednau, M. \& Hahn-Hägerdal, B. (1995). The influence of limiting and non-limiting growth conditions on glucose and maltose metabolism in Lactococcus lactis ssp. lactis strains. Appl Microbiol Biotechnol 42, 931-938.

Sorimachi, H., Ohmi, S., Emori, Y., Kawasaki, H., Saido, T. C., Ohno, S., Minami, Y. \& Suzuki, K. (1990). A novel member of the calcium-dependent cysteine protease family. Biol Chem HoppeSeyler (Suppl.) 371, 171-176.

Terzaghi, B. E. \& Sandine, W. E. (1975). Improved medium for lactic streptococci and their bacteriophages. Appl Environ Microbiol 29, 807-813.

Thomas, T. D., Turner, K. W. \& Crow, V. L. (1980). Galactose fermentation by Streptococcus lactis and Streptococcus cremoris: pathways, products, and regulation. J Bacteriol 144, 672-682.

Thompson, J. (1980). Galactose transport systems in Streptococcus lactis. J Bacteriol 144, 683-691.

Thompson, J. (1987). Regulation of sugar transport and metabolism in lactic acid bacteria. FEMS Microbiol Rev 46, 221-231.

Thompson, J. \& Saier, M. H., Jr (1981). Regulation of methyl- $\beta$-Dthiogalactopyranoside-6-phosphate accumulation in Streptococcus lactis by exclusion and expulsion mechanisms. J Bacteriol 146, 885-894.

Thompson, J. D., Turner, K. W. \& Thomas, T. D. (1978). Catabolite inhibition and sequential metabolism of sugars by Streptococcus lactis. J Bacteriol 133, 1163-1174.

Vargas, M. A. \& Orozco, E. (1993). Entamoeba bistolytica: changes in the zymodeme of cloned nonpathogenic trophozoites cultured under different conditions. Parasitol Res 79, 353-356.

Vieira, J. D. \& Messing, J. (1982). The pUC plasmids, an M13mp7derived system for insertion mutagenesis and sequencing with synthetic universal primers. Gene 19, 259-268.

Received 27 June 1996; revised 12 September 1996; accepted 16 October 1996. 